\title{
Implementation of LKPD to Improve Student Learning Outcomes
}

\author{
Uun Inayati \\ SD Muhammadiyah 02 Noyontaan \\ uuninayati@gmail.com
}

\section{Article History}

accepted 01/11/2020

approved 08/11/2020

published 15/11/2020

\begin{abstract}
The purpose of this study was to describe the application of LKPD to improve mathematics learning outcomes about time units in class III students. The type of research used is Classroom Action Research (CAR) which is carried out in three cycles, each cycle consisting of planning, implementation, observation, and reflection stages. . The subjects of this study were students of class III SD Muhammadiyah 02 Noyontaan in the 2019/2020 academic year, totaling 21 students. The method used is through the application of LKPD. Where each cycle is carried out 2 meetings. Each cycle consists of four activities, namely planning, implementing actions, observing and evaluating, and reflecting. Based on the research results, the results achieved in each cycle have increased. In the first cycle the average score was 75, and only 15 students or $75 \%$ of the students passed. In cycle II the average score is 75 , students who complete 15 people or $70 \%$. In cycle III, the average score of 84 students who completed 21 people or $100 \%$. Based on the results obtained, it can be seen that the application of the learning model using LKPD can improve the mathematics learning outcomes of grade III students of SD Muhammadiyah 02 Noyontaan.
\end{abstract}

Keywords: learning outcomes, LKPD

\begin{abstract}
Abstrak
Tujuan Penelitian ini adalah untuk Mendeskripsikan penerapan LKPD untuk meningkatkan hasil belajar matematika tentang satuan waktu pada peseta didik kelas III SD Muhammadiyah 02 Noyontaan tahun Pelajaran 2020/2021. Jenis penelitian yang digunakan adalah Penelitian Tindakan Kelas ( PTK ) yang dilakukan oleh peneliti dan guru kolaborator pada III SD Muhammadiyah 02 Noyontaan melalui 3 siklus. Metode yang digunakan adalah melalui penerapan LKPD. Dimana setiap siklus dilaksanakan 2 kali pertemuan. Setiap siklus terdiri dari empat kegiatan yaitu perencanaan, pelaksanaan tindakan, observasi dan evalusi, serta refleksi. Berdasarkan hasil penelitian, hasil yang dicapai pada setiap siklus mengalami peningkatan. Pada siklus I nilai rata - rata 75 , dan hanya 15 siswa atau $75 \%$ siswa yang tuntas. Pada siklus II nilai rata - rata 75 , siswa yang tuntas 15 orang atau $70 \%$. Pada siklus III nilai rata - rata 84 siswa yang tuntas 21 orang atau $100 \%$. Berdasarkan hasil yang diperoleh tersebut dapat diketahui bahwa penerapan model pembelajaran menggunakan LKPD dapat meningkatkan hasil belajar matematika siswa kelas III SD Muhammadiyah 02 Noyontaan.
\end{abstract}

Kata kunci : hasil belajar, satuan waktu dan LKPD

Social, Humanities, and Education Studies (SHEs): Conference Series https://jurnal.uns.ac.id/shes

p-ISSN 2620-9284

e-ISSN 2620-9292 


\section{PENDAHULUAN}

Latar belakang dari penelitian ini adalah peserta didik menganggap mata pelajaran Matematika itu susah karena berhubungan dengan angka, menghitung dan beranggapan guru Matematika itu keras. Kurangnya kreativitas guru dalam mengajar sehingga membuat Peserta didik menjadi jenuh, cepat bosan dan menjadi mengantuk. Rendahnya pemahaman peserta didik mengenai materi materi satuan waktu yang ditandai dengan data nilai ulangan harian mata pelajaran Matematika yang hasilnya masih kurang memuaskan.

Berdasarkan survey yang dilakukan, maka ditemukan beberapa masalah dalam pembelajaran Matematika, Peserta didik menganggap mata pelajaran Matematika itu susah karena berhubungan dengan angka, menghitung dan beranggapan guru Matematika itu keras. Kurangnya kreativitas guru dalam mengajar sehingga membuat Peserta didik menjadi jenuh, cepat bosan dan menjadi mengantuk. Rendahnya pemahaman peserta didik mengenai materi materi satuan waktu yang ditandai dengan data nilai ulangan harian mata pelajaran Matematika yang hasilnya masih kurang memuaskan. Kebanyakan peserta didik mendapatkan nilai di bawah KKM, dengan nilai KKM yang telah ditentukan yaitu 70. Dari 21 peserta didik kelas III SD Muhammadiyah 02 Noyontaan Pekalongan terdapat 30\% (6 siswa ) yang memenuhi KKM dan 70\% (15 siswa) tidak mencapai KKM. Rendahnya capaian nilai Matematika karena alat bantu yang kurang memadai, Peserta didik yang masih kurang memperhatikan pelajaran saat pembelajaran berlangsung, rendahnya pemahaman peserta didik tentang materi satuan waktu, kurangnya kreativitas guru dalam menyampaikan materi pembelajaran. Sebagai pendidik, guru harus memiliki kreativitas dalam mengajar, sehingga suasana pembelajaran menjadi menyenangkan dan siswa menjadi nyaman serta antusias dalam mengikuti proses pembelajaran. Melihat faktor-faktor yang mempengaruhi rendahnya nilai ulangan siswa, kemudian peneliti berdiskusi dengan guru mengenai strategi pembelajaran yang tepat untuk mengatasi permasalahan tersebut. Penggunaan strategi yang tepat dalam proses pembelajaran Matematika dapat meningkatkan hasil belajar siswa. Strategi yang diperlukan adalah strategi yang menyenangkan, berpusat pada siswa. Siswa dapat berperan aktif dalam pembelajaran. Maka penulis menggunakan LKPD yang menarik sebagai solusi yang tepat untuk dalam permasalahan yang ada di Kelas III SD Muhammadiyah 02 Noyontaan Pekalongan.

Setelah mengetahui latar belakang masalah yang dijelaskan diatas maka penulis dalam melakukan penelitian ini perlu memberikan judul "penerapan Ikpd untuk meningkatkan hasil belajar peserta didik pada materi satuan waktu di kelas iii sd muhammadiyah 02 noyontaan tahun pelajaran 2020/2021"

Melalui penerapan LKPD yang merupakan sebuah kumpulan lembaranlembaran kertas yang berisi materi, tugas-tugas yang harus dilakuakn dalam kegiatan pembelajaran, serta langkah-langkah yang harus dilakukan dalam pembelajaran. Tugas-tugas yang diberikan dalam LKPD harus jelas dan sesuai dengan materi yang diajarkan sehingga kompetensi dasar dan tujuan pembelajaran yang akan dicapai dapat tercapai dengan baik, sesuai dengan apa yang diharapkan.

Menurut Prastowo(2012: 205) dalam menyiapkan LKPD, ada beberapa syarat yang harus dipenuhi oleh pendidik. Pendidik harus cermat, serta memiliki pengetahuan dan ketrampilan yang memadai untuk bisa membuat LKPD yang bagus. Sebuah LKPD harus memenuhi kriteria yang berkaitan dengan tercapai atau tidaknya sebuah kompetensi dasar yang harus dikuasai dan dipahami oleh peserta didik.

Berdasarkan hasil identifikasi dan analisis masalah penulis akan melakukan perbaikan melalui PTK yang akan difokuskan "Bagaimana penerapan LKPD untuk meningkatkan hasil belajar peserta didik pada materi satuan waktu di kelas III SD Muhammadiyah 02 Noyontaan tahun Pelajaran 2020/2021?" 
Dari latar belakang masaah diatas, maka tujuan penelitian ini adalah Mendeskripsikan penerapan LKPD untuk meningkatkan hasil belajar matematika tentang satuan waktu pada peseta didik kelas III SD Muhammadiyah 02 Noyontaan tahun Pelajaran 2020/2021.

\section{METODE}

Penelitian ini adalah penelitian tindakan kelas. Dilaksanakannya penelitian tindakan kelas III SD Muhammadiyah 02 Noyontaan, dengan jumlah 21 siswa. Kendala yang muncul dalam proses pembelajaran seperti kurangnya hasil belajar siswa pada mata pelajaran matematika materi satuan waktu. Untuk mengatasi hal tersebut maka perlu upaya perbaikan proses pembelajaran oleh guru, sebab hanya gurulah yang paling tahu tentang keadaan kelas yang dikelolanya.

Oleh karena itu Penerapan Kurikulum 2013 harus didukung dengan berbagai perangkat pembelajaran yang secara aktif mengembangkan peserta didik. Salah satu bahan ajar yang digunakan dalam kurikulum 2013 adalah Lembar Kerja Peserta didik (LKPD). Berdasarkan wawancara dan analisis sederhana mengenai proses pembelajaran siswa diperoleh bahwa pembelajaran siswa yang sekarang masih belum sesuai dengan keinginan kurikulum yang berlaku sehingga peserta didik masih belum dapat mengembangkan siswa secara aktif. Metode yang digunakan peneliti adalah menerapkan LKPD dalam pembelajaran untuk meningkatkan hasil belajar peserta didik pada materi satuan waktu di kelas III.

Dengan adanya perubahan Kurikulum menuntut guru dapat melaksanakan pembelajaran sesuai kurikulum yang berlaku. Oleh karena itu dibutuhkan adanya perangkat pembelajaran yang aktif mengembangkan peserta didik. Lembar kerja peserta didik (LKPD) merupakan sarana untuk membantu dan mempermudah dalam kegiatan belajar mengajar sehingga terbentuk interaksi efektif antara peserta didik dengan pendidik, dapat meningkatkan aktivitas dan prestasi belajar peserta didik

Penelitian ini akan dilaksanakan di SD Muhammadiyah 02 Noyontaan kota Pekongan, dan akan dilaksanakan tanggal 19 Oktober - 10 November 2020. Adapun yang menjadi alasan penulis untuk memilih lokasi ini adalah karena bertepatan dengan tempat melaksanakan tugas sebagai guru kelas sehingga dapat memberi kemudahan bagi penulis dalam melaksanakan penelitian ini.

\section{HASIL DAN PEMBAHASAN}

Dari hasil evaluasi pada siklus I ini, dapat dikatakan bahwa hasil belajar peserta didik yang mendapat nilai tuntas dengan KKM 70 sebanyak 15 peserta didik atau $70 \%$ dan yang belum tuntas sebanyak 6 siswa atau $30 \%$. Dari jumlah peserta didik yang ada di kelas III SD Muhammadiyah 02 Noyontaan dengan nilai ratarata kelasnya adalah 75 . Sehingga dalam upaya peningkatan hasil belajar peserta didik dalam menguasai pelajaran belum berhasil. Hal ini dikarenakan masih terdapat kekurangan dalam proses pembelajaran siklus I. Kekurangan itu antara lain:

a) Masih ada beberapa peserta didik yang kurang memperhatikan materi yang diajarkan dan menganggap bahwa matematika itu susah.

b) Aplikasi pembelajaran berupa zoom juga masih terlalu baru untuk peserta didik dan guru.

c) Ada peserta didik yang tidak dapat mengikuti pembelajaran karena handphone orang tua tidak support untuk aplikasi zoom.

Hasil dari observasi / pengamatan dikumpulkan dan dianalisis. Ternyata pada siklus II, peserta didik kelas III SD Muhammadiyah 02 Noyontaan semua sudah tuntas belajar atau semua peserta didik menguasai materi pelajaran dengan baik. Hal ini dapat dilihat dari motivasi siswa dalam pembelajaran semakin tinggi melalui mediamedia yang digunakan, penerapan LKPD yang efektif, teknik pembelajaran dan 
kemampuan guru dalam menyampaiakan materi pelajaran semakin baik, sehingga guru merasa lebih menguasai pelaksanaan proses belajar mengajar. Jumlah siswa yang tuntas 21 orang atau $100 \%$ dengan rata-rata $84 \%$. Persentase keaktifan $80 \%$ sudah termasuk kategori sangat aktif. Dalam siklus III ini terlihat kegiatan pembelajaran dengan menerapkan LKPD materi satuan waktu sudah menunjukkan hasil yang memuaskan.

Hasil penelitian tindakan kelas yang dilakukan dalam 3 siklus. untuk mengetahui bagaimana cara guru menggunakan model penerapan LKPD dalam proses pembelajaran matematika, khususnya materi satuan waktu. Berikut table rentang nilai hasil belajar peserta didik kelas III pada materi satuan waktu.

Tabel 1. Hasil Belajar Peserta Didik

\begin{tabular}{|c|c|c|c|c|c|c|}
\hline \multirow[b]{2}{*}{ Nilai } & \multicolumn{2}{|c|}{ Siklus I } & \multicolumn{2}{|c|}{ Siklus II } & \multicolumn{2}{|c|}{ Siklus III } \\
\hline & $\begin{array}{c}\text { Pembelaja } \\
\text { ran } 1\end{array}$ & $\begin{array}{l}\text { Pembelaja } \\
\text { ran } 2\end{array}$ & $\begin{array}{c}\text { Pembelaja } \\
\text { ran } 1\end{array}$ & $\begin{array}{c}\text { Pembelaja } \\
\text { ran } 2\end{array}$ & $\begin{array}{c}\text { Pembelaja } \\
\text { ran } 1\end{array}$ & $\begin{array}{c}\text { Pembelaja } \\
\text { ran } 2\end{array}$ \\
\hline $0-20$ & 0 & 0 & 0 & 0 & 0 & 0 \\
\hline $\begin{array}{l}21- \\
40\end{array}$ & 1 & 0 & 1 & 0 & 0 & 0 \\
\hline $\begin{array}{l}41- \\
60\end{array}$ & 5 & 5 & 5 & 0 & 2 & 0 \\
\hline $\begin{array}{l}61- \\
80\end{array}$ & 8 & 8 & 8 & 11 & 11 & 10 \\
\hline $\begin{array}{l}81- \\
100\end{array}$ & 7 & 8 & 7 & 10 & 8 & 11 \\
\hline
\end{tabular}

Hasil observasi guru tersebut adalah sebagai berikut pada siklus I analisis data observasi aktifitas guru dengan persentase $64,28 \%$, dan siklus II dengan persentase $75 \%$, dan pada siklus ke III mengalami peningkatan yaitu dengan persentase $92,85 \%$. Sedangkan hasil observasi aktifitas siswa pada siklus I dengan persentase $58 \%$, pada siklus II dengan persentase $69,5 \%$, pada siklus III $80 \%$. Hasil evaluasi siswa pada proses pembelajaran, pada siklus I siswa yang tuntas hanya 15 peserta didik atau $70 \%$ dan yang belum tuntas sebanyak 6 siswa atau $30 \%$. pada siklus II siswa yang tuntas 21 orang dengan nilai rata-rata kelas $64,85 \%$, pada siklus siswa yang tuntas 21 orang dengan rata - rata $84 \%$, ini sudah mencapai kriteria ketuntasan yang yang diharapkan.

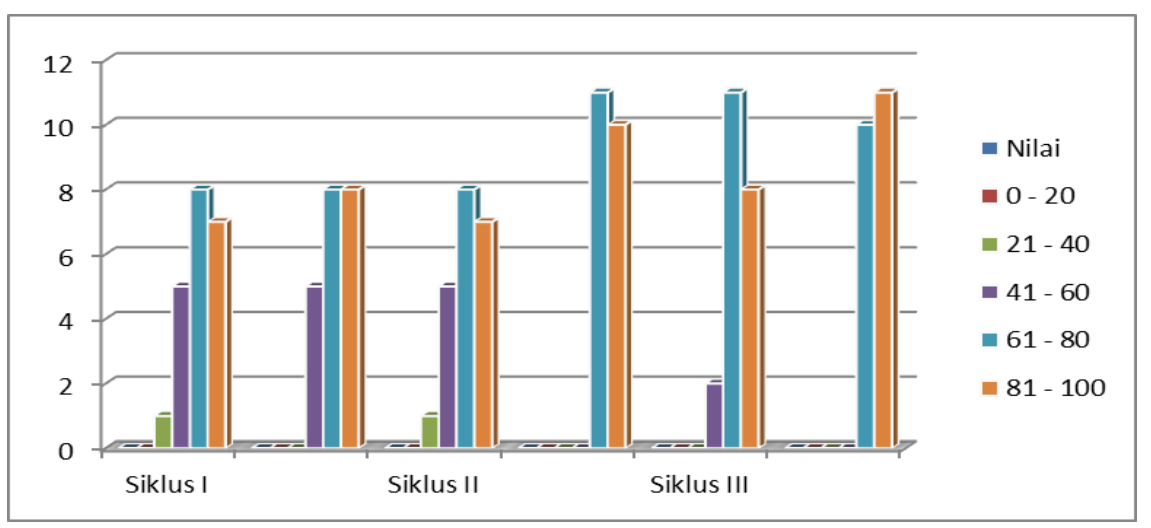

Gambar 1. Hasil Belajar Peserta Didik Kelas III Pada Materi Satuan Waktu 


\section{SIMPULAN}

Penelitian tindakan kelas yang telah dilaksanakan dapat disimpulkan bahwa "penerapan LKPD dalam pembelajaran dapat meningkat hasil belajar siswa pada mata pelajaran matematika materi satuan waktu pada siswa kelas III SD Muhammadiyah 02 Noyontaan.

\section{DAFTAR PUSTAKA}

Arikunto, Suharsini. 1960. Prosedur Penelitian. Jakarta : Rineka Cipta.

Chatarina. 2004. Psikologi Belajar dan Pembelajaran. Semarang: UNNES.

Hadi, Sutrisno. 1987/1989, Metodologi Researce II dan III, Yogyakarta, yayasan Penerbit Fakm Psikologi Universitas Gajah Mada.

Heruman.2010.Model Pembelajaran Matematika di SekolahDasar.Bandung:PT Remaja Rosdakarya

Marwiyanto, dkk.2008.Matematika untuk SD dan MI Kelas 3.Jakarta:PT.Piranti Darma Kalokatama

Prastowo, Andi (2014) Panduan Kreatif Membuat Bahan Ajar Inovatif. Jokyakarta Diva Press

Riadi, Muchlisin. 2019. Penelitian Tindakan Kelas https://www.kajianpustaka.com/2019/03/penelitian-tindakan-kelasptk.html

Sudrajat, Akhmad. 2008. https://akhmadsudrajat.wordpress.com/

Umbaryati.2020.Pengertian LKPD https://journal.unnes.ac.id/sju/index.php/prisma/article/download/21473 /10157/

Widjayanti.2008.Media Lembar Kerja Peserta Didik.Jakarta: Rineka 